\title{
Analysis of Summer 2002 Melt Extent on the Greenland Ice Sheet using MODIS and SSM/I Data
}

\author{
Dorothy K. Hall*, Richard S. Williams, Jr.**, Konrad Steffen+, and Janet Y.L. Chien++ \\ *Code 971, NASA/Goddard Space Flight Center, Greenbelt, MD 20771 USA \\ dorothv.k.hall@nasa.gov \\ **U.S. Geological Survey, Woods Hole, MA 02543-1598 USA rswilliams@usgs.gov \\ +CIRES/University of Colorado at Boulder, CO 80309-0216 USA konrad.steffen@.colorado.edu \\ +SAIC, Beltsville, MD 20705 USA janet@glacier.gsfc.nasa.gov
}

\begin{abstract}
Previous work has shown that the summer of $2002 \mathrm{had}$ the greatest area of snow melt extent on the Greenland ice sheet ever recorded using passive-microwave data. In this paper, we compare the $0^{\circ}$ isotherm derived from the Moderate-Resolution Imaging Spectroradiometer (MODIS) instrument, with Special Sensor Microwave/Imager (SSM//)-derived melt, at the time of the maximum melt extent in 2002 . To validate the MODISderived land-surface temperatures (LSTs), we compared the MODIS LSTs with air temperatures from nine stations (using 11 different data points) and found that they agreed to within 2.3 $\pm 2.09^{\circ} \mathrm{C}$, with station temperatures consistently lower than the MODIS LSTs. According to the MODIS LST, the maximum surface melt extended to $\mathbf{2 3 0 0} \mathrm{m}$ in southern Greenland; while the SSM/I measurements showed that the maximum melt extended to nearly $2700 \mathrm{~m}$ in southeastern Greenland. The MODIS and SSM/I data are complementary in providing detailed information about the progression of surface and nearsurface melt on the Greenland ice sheet.
\end{abstract}

\section{INTRODUCTION}

Previous work using data from the Special Sensor Microwave/Imager (SSM/I) has shown that the summer of 2002 had the greatest melt extent ever recorded using passivemicrowave data [1], [2], [3]. If the Greenland ice sheet were to melt completely, as has happened in the past [4], it would contribute $-6.5 \mathrm{~m}$ of water to sea level [5], thus analysis of snow-melt patterns and trends on the Greenland ice sheet are of great importance. Moreover, surface melt can act to enhance the flow of outlet glaciers through crevasse overdeepening and contribute to the very rapid thinning of outlet glaciers [6]. In this paper, we explore the relationship between the Moderate-Resolution Imaging Spectroradiometer (MODIS)-derived $0^{\circ} \mathrm{C}$ isotherm and SSM/I-derived maximum melt zones for the period $26 \mathrm{July}-1$ August 2002.

\section{IL BACKGROUND}

A 16-year dataset from the SSM/I utilized the Cross-Polarized Gradient Ratio (XPGR) (the normalized difference between the $19-\mathrm{GHz}$ horizontal channel and the $37-\mathrm{GHz}$ vertical channel of the SSM/I) to study the areal extent of melt extent on the Greenland ice sheet [1]. A trend of increasing melt area of $+4.4 \%$ per year was observed from 1979-1991 which corresponds to the observed increase in coastal temperatures of $+1.1^{\circ} \mathrm{C}$ during that period [1]. Melt area is shown to increase by $47 \%$ for a $+1.0^{\circ} \mathrm{C}$ rise in temperature [1]. The areal extent of meltwater on the Greenland ice sheet peaks in late July.

Analysis of snow-melt extent on the Greenland ice sheet using passive-microwave data from the SSM/I during the last 24 years has shown that the maximum melt area increased $16 \%$ from 1979-2002, and in particular, the northern and northeastern part of the ice sheet experienced extreme melt extending up to 2000-m elevation [3]. Furthermore, Steffen and Box [7] found that the annual mean air temperature was $2{ }^{\circ} \mathrm{C}$ warmer in the central part of Greenland for the time period 1995-1999, as compared to the period from 1951-1960.

Satellite-derived ice-surface temperatures (ISTs) of sea ice [8] and ice sheets [9] and [10] have been studied for many years. An IST retrieval algorithm was developed [8] for the Greenland ice sheet using thermal radiances from bands 4 (10.5-11.5 $\mu \mathrm{m})$ and $5(11.5-12.5 \mu \mathrm{m})$ of National Oceanic and Atmospheric Administration - 11 (NOAA-11) satellite data. Clear-sky surface temperatures were found to compare well with Advanced Very High Resolution Radiometer (AVHRR)derived temperatures with a maximum difference of $0.6^{\circ} \mathrm{K}$. Using a brightness temperature threshold of $31^{\circ} \mathrm{K}$ above the winter mean to identify melt periods, Mote et al. [11] showed that an increase in SSM/I brightness temperature $\left(T_{B}\right)$ is associated with melting of surface snow. Stroeve and Steffen [10] studied AVHRR data of the Greenland ice sheet from 1989-1993, and presented monthly-mean temperature maps with an accuracy of greater than $1^{\circ} \mathrm{K}$ during the summer, but noted that there was a reduction in the accuracy during the polar night when cloud detection is difficult.

The emissivity of snow changes rapidly with melt due to an increase in the liquid-water content of the snow and its attendant high dielectric constant as compared to that of air and ice. Meltwater increases the dielectric constant of the iceair-water mixture [12] and [13], thus raising the emissivity and increasing absorption relative to volume scattering which reduces the scattering albedo and enhances emission [14]. The change in $T_{B}$ with melt is frequency-dependent. This is the principle behind passive-microwave detection of melt on an ice sheet. 


\section{METHODOLOGY}

The MODIS land-surface temperature (LST) product, MOD11 [15], was registered to the digital-elevation model (DEM) of Greenland from Bamber et al. [16] and to an SSM/I-derived melt map showing the maximum melt from 26 July to 1 August 2002. MODIS measures the thermal radiation emitted from different features, such as rock, soil and snow, on the Earth's surface; the emissivity of the different features is used to determine LST. To validate the MOD11 LSTs over the ice sheet, 11 LSTs were compared with automated weather station (AWS) temperatures from nine different stations at the same locations derived within an hour of each other. (Eleven additional points were rejected due to the presence of cloud or fog at or adjacent to the MODIS LST pixel.) 2-m AWS temperatures were consistently lower than the MODIS LSTs even after an offset was subtracted from the station temperatures (see below), but the temperatures agreed to within $2.3 \pm 2.09^{\circ} \mathrm{C}$. The AWS temperatures were measured with thermocouples in radiation shields and have an accuracy of $0.2^{\circ} \mathrm{C}$, logged every 15 seconds and averaged over an hour. It is likely that utilizing a specific algorithm to detect icesurface temperature will reduce the MODIS-derived IST measurement errors further (see [17] for example). A MODIS band $1(0.62-0.67 \mu \mathrm{m}), 4(0.545-0.565 \mu \mathrm{m})$ and $6(1.628-$ $0.652 \mu \mathrm{m}$ ) combination image was used to locate clouds visually.

We calculated the offset in temperature and subtracted that value, $1.05^{\circ} \mathrm{K}$, from each AWS temperature. Figure 1 shows the hourly air temperature record for the Summit Station for 2001 versus surface temperature to provide a more-realistic "surface temperature." The surface temperatures were derived from a research tower with ventilated air temperature sensors and an infrared sensor that is $10 \mathrm{~cm}$ above the surface. The "residual mean square" was used as the offset value.

\section{RESULTS AND DISCUSSION}

We found good correspondence between the MOD11 $0^{\circ} \mathrm{C}$ isotherm and the upper boundary of the maximum melt from SSM/I in northern and southern Greenland and parts of southwestern Greenland (Figure 2). However, in most of the eastern and western parts of the ice sheet, and other parts of northern Greenland, the MOD11 $0^{\circ} \mathrm{C}$ isotherm is at a lower elevation than is the SSM/1-derived maximum melt (Table 1) by up to $\sim 900 \mathrm{~m}$. Elevations were determined from the digital-elevation map of Bamber et al. [16].

The melt detected by the SSM/I sensor extends below the surface so that the MODIS- and SSM/I-derived melt extent should not necessarily be the same because the MOD11 product depicts the surface temperature of the ice only. And Figure 2 clearly shows that the MODIS- and SSM/I-derived snow-melt areas are generally not the same.

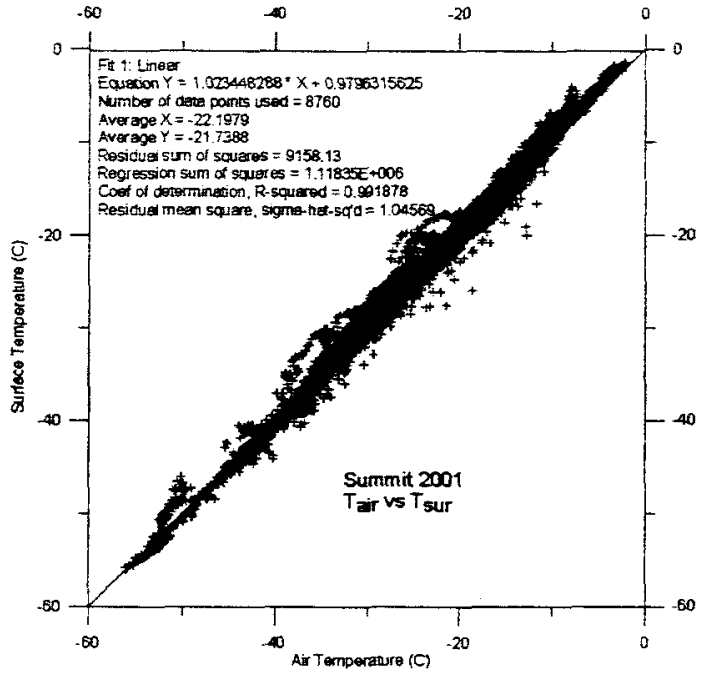

Figure 1. Hourly air temperatures versus surface temperatures in 2001 for Summit Station, Greenland. The "residual mean square" represents the average offset between the 2-m air and surface temperatures.

Table I

ELEVATION OF MODIS-DERIVED MAXIMUM SURFACE TEMPERATURE FROM THE MOD11 [15] PRODUCT, AND FROM SSM/ FOR THE DATES 26 JULY TO 1 AUGUST 2002. BLACK DOTS ON FIGURE 2 CORRESPOND TO LOCATION INFORMATION IN THIS TABLE.

\begin{tabular}{|c|c|c|}
\hline $\begin{array}{c}\text { Location on the } \\
\text { Greenland ice } \\
\text { sheet }\end{array}$ & $\begin{array}{c}\text { Maximum elevation of } \\
\text { melt from MOD11 }\end{array}$ & $\begin{array}{c}\text { Maximum elevation of } \\
\text { melt from SSM/I }\end{array}$ \\
\hline $\begin{array}{c}\text { Northern } \\
\text { Greenland }\end{array}$ & $588 \mathrm{~m}$ & $1484 \mathrm{~m}$ \\
\hline $\begin{array}{c}\text { Northeastern } \\
\text { Greenland }\end{array}$ & $1247 \mathrm{~m}$ & $1856 \mathrm{~m}$ \\
\hline $\begin{array}{c}\text { Southeastern } \\
\text { Greenland }\end{array}$ & $2214 \mathrm{~m}$ & $2321 \mathrm{~m}$ \\
\hline $\begin{array}{c}\text { Southem } \\
\text { Greenland }\end{array}$ & $2321 \mathrm{~m}$ & $1946 \mathrm{~m}$ \\
\hline $\begin{array}{c}\text { Southwestern } \\
\text { Greenland }\end{array}$ & $1306 \mathrm{~m}$ & $1597 \mathrm{~m}$ \\
\hline $\begin{array}{c}\text { Northwestern } \\
\text { Greenland }\end{array}$ & $832 \mathrm{~m}$ & \\
\hline
\end{tabular}

The passive microwave melt algorithm, the XGPR, uses 37 and $19 \mathrm{GHz}$ channels and has a nominal spatial resolution of about $50 \mathrm{~km}$. The XGPR is quite conservative in detecting melt, because the two frequencies have different penetration depths. (Using only the $37 \mathrm{GHz}$ channel for melt detection provides larger melt areas.) The SSM/I is very sensitive to the amount of free water in the snow overlying glacier ice (less than $1 \%$ of free water per volume), is not affected by cloud cover over Greenland, but has relatively poor resolution. 
Furthermore, passive-microwave sensors cannot detect the surface temperature, whereas the MODIS instrument is sensitive to changes in surface temperature and provides good spatial resolution in the thermal-infrared bands (1-km pixels) for a detailed evaluation of the surface melt conditions, but only under clear skies.

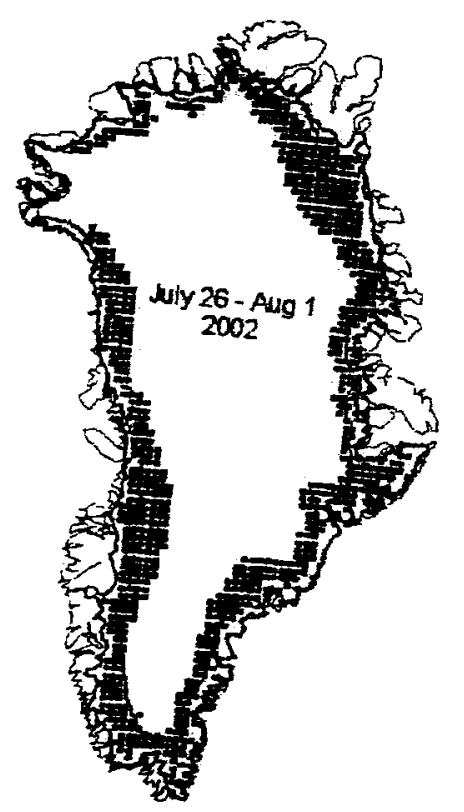

Figure 2. Map of Greenland showing SSM/I-derived maximum melt (red dots) for the period 26 July -1 August 2002 , and the MODIS-derived $0^{\circ} \mathrm{C}$ isotherm (green line) (from the MOD11 LST product [15]. Black dots correspond to positions of measurements in Table 1.

In future work, we will assess the differences in elevation of snow melt reported previously as compared to results reported herein. We will also determine if the MOD11 LST product is optimum for determining IST over Greenland ice sheet, or if an algorith developed for determination of IST over sea ice [8] and [17] would provide closer correspondence with AWS temperatures. In addition, more years of MODIS data will be compared with the SSM/I melt maps.

While it is difficult to use different satellite sensors to derive the same geophysical parameter, we show that in fact the MODIS and SSM/I data are complementary in providing detailed information about the maximum snow melt on the Greenland ice sheet, both surficial melt, and melt within the top layers of the snow and firn that overlie the glacier ice.

\section{ACKNOWLEDGMENTS}

The authors thank Jonathan Bamber/University of Bristol, UK, for providing us the DEM of Greenland, and Zhengming Wan/UCSB, for information about the MODIS land-surface temperature product.

\section{REFERENCES}

[1] W. Abdalati and K. Steffen, "Snowmelt on the Greenland Ice Sheet as derived from passive microwave satellite data," Journal of Climate, 10:165-175, 1997.

[2] W. Abdalati and K. Steffen, "Greenland ice sheet melt extent: 1979-1999," Journal of Geophysical Research, 106(D24):33,983-33,989, 2001.

[3] K. Steffen, S. V. Nghiem , R. Huff, and G. Neumann, "The melt anomalies of 2002 and 2003 on the Greenland ice sheet from passive and active microwave satellite observations," Geophysical Research Letters, submitted.

[4] R.M. Koemer, "Ice core evidence for extensive melting of the Greenland ice sheet in the last interglacial," Science, 244(4907:964-968, 1989.

[5] R.S. Williams, Jr. and D.K. Hall, "Glaciers," in, R.J. Gurney, J.L. Foster and C.L. Parkinson (eds.), Atlas of Satellite Observations related to Global Change," Cambridge University Press, pp. 401-422, 1993.

[6] H.J. Zwally, W. Abdalati, T. Herring, K. Larsen, J. Saba, and K. Steffen, "Surface melt-induced acceleration of Greenland ice-sheet flow," Science, 297, 218-222, 2002.

[7] K. Steffen and J. Box, "Surface climatology of the Greenland ice sheet: Greenland climate network 1995-1999," Journal of Geophysical Research, 106(D24):33,951-33,964, 2001.

[8] J. Key and M. Haefliger, "Arctic ice surface temperature retrieval from AVHRR thermal channels," Journal of Geophysical-Research, 97(D5):5885-5893, 1992.

[9] M. Haefliger, K. Steffen and C. Fowler, "AVHRR surface temperature and narrow-band albedo comparison with ground measurements for the Greenland ice sheet," Annals of Glaciology, 17:49-54, 1993.

[10] J. Stroeve, and K. Steffen, "Variability of AVHRRderived clear-sky surface temperature over the Greenland ice sheet," Journal of Applied Meteorology, 37:23-31, 1998.

[11] T.L. Mote, M.R. Anderson, K.C. Kuivinen and Clinton M. Rowe, "Passive microwave-derived spatial and temporal variations of summer melt on the Greenland ice sheet," Annals of Glaciology, 17:233-238, 1993. 
[12] F.T. Ulaby, R.K. Moore and A.K. Fung, Microwave remote sensing, active and passive. Vol. 3, From Theorv to Applications, Reading, MA, Addison-Wesley Publishing Co., 2162 p., 1986.

[13] T.L. Mote and M.R. Anderson, "Variations in snowpack melt on the Greenland ice sheet based on passive-microwave measurements," Journal of Glaciology, 41(137):51-60, 1995.

[14] A.T.C. Chang, P. Gloersen, T. Schmugge, T.T. Wilheit and H.J. Zwally, "Microwave emission from snow and glacier ice," Journal of Glaciology, 16(74):23-29, 1976.

[15] Z. Wan, Y. Zhang, Q. Zhang, and Z.-L. Li, "Validation of the land-surface temperature products retrieved from Terra Moderate Resolution Imaging Spectroradiometer data," Remote Sensing of Environment, 83:163-180, 2002.

[16] J.L. Bamber, S. Ekholm and W.B. Krabill, "A new, highresolution digital elevation model of Greenland fully validated with airborne laser altimeter data, Journal of Geophysical Research, 106(B4):6733-6745, 2001.

[17] D.K. Hall, J.R. Key, K.A. Casey, G.A. Riggs and D.J. Cavalieri, "Sea ice surface temperature product from MODIS," IEEE Transactions on Geoscience and Remote Sensing, 42(5): 1076-1087, 2004. 


\section{Analysis of Summer 2002 Melt Extent on the Greenland Ice Sheet using MODIS and SSM/I Data}

Dorothy K. Hall*. Richard S. Williams. Jr.**, Konrad Steffen+, and Janet Y.L. Chien+t *Code 974, NASA/Goddard Space Flight Center. Greenbelt. MD 20771 USA Dorothv.K.Hall@nasa.gov

**U.S. Geological Survey, Woods Hole, MA 025+3-1598 USA

+ CIRES/University of Colorado at Boulder, CO 80309-0216 USA

++SAIC. Beltsville. MD 20705 USA

\section{Popular Summary}

Previous work has shown that the summer of 2002 had the greatest area of surface and near-surface melt on the Greenland ice sheet ever recorded using passive-microwave data. In this paper, we compare the $0^{\circ}$ isotherm derived from the Moderate-Resolution Imaging Spectroradiometer (MODIS) instrument, with Special Sensor Microwave/Imager (SSM/1)-derived melt, at the time of the maximum melt in 2002. According to the MODIS-derived land-surface temperatures, the maximum surface melt extended to $\sim 2300 \mathrm{~m}$ in southern Greenland; while the SSM/I measurements showed that the maximum melt extended to nearly $2700 \mathrm{~m}$ in southeastern Greenland. In this paper, we explore the relationship between the Moderate-Resolution Imaging Spectroradiometer (MODIS)-derived $0^{\circ} \mathrm{C}$ isotherm and SSM/I-derived maximum melt zones for the period 26 July - 1 August 2002. We find that the MODIS and SSM/I data are complementary in providing detailed information about the progression of surface and near-surface melt on the Greenland ice sheet.

\section{Significance}

Previous work using data from the Special Sensor Microwave/Imager (SSM/I) has shown that the summer of 2002 had the greatest melt ever recorded using passive-microwave data. If the Greenland ice sheet were to melt completely, as has happened in the past, it would contribute $-6.5 \mathrm{~m}$ of water to sea level which would inundate many coastal areas, thus analysis of melt patterns on the Greenland ice sheet are of great importance. Moreover, surface melt can act to enhance the flow of outlet glaciers through crevasse overdeepening and contribute to the very rapid thinning of outlet glaciers. 